Jurnal Farmamedika Vol. 5, No. 2 Desember 2020

\title{
PENAPISAN MOLEKULAR KANDIDAT OBAT SINTETIK TUBERKULOSIS TERHADAP PROTEIN TIROSIN KINASE Mycobacterium tuberculosis
}

\author{
Harry Noviardi*1 $^{*}$, Eem Masaenah ${ }^{1}$, Rizky Ramadhan ${ }^{1}$ \\ 1Program Studi S1 Farmasi, Sekolah Tinggi Teknologi Industri dan Farmasi, Bogor \\ *Korespondensi : harry.noviardi@gmail.com
}

\begin{abstract}
ABSTRAK
Mycobacterium tuberculosis (Mtb) merupakan bakteri penyebab infeksi pada penyakit Tuberkulosis (TB). Sebagian besar obat TB yang dikembangkan pada saat ini mulai dilakukan sejak 40 tahun lalu. Obat tersebut memungkinkan terjadinya resistensi terhadap Mycobacterium tuberculosis. Oleh karena itu perlu dikembangkan obat baru yang dapat mengobati TB. Protein tirosin kinase dapat dijadikan target pengobatan TB karena memainkan peran kunci dalam fisiologi Mycobacterium tuberculosis dan patogenesis. Pada penelitian ini dilakukan analisis efektifitas dari senyawa-senyawa turunan sintetik sebagai inhibitor pada penambatan molekular terhadap protein tirosin kinase yang berperan penting pada penyakit tuberculosis. Senyawa turunan sintetik dilakukan analisis penambatan molecular. Penentuan nilai konstanta inhibisi serta visualisasi interaksi obat dilakukan menggunakan Pymol dan Discovery Visualizer. Aktivitas farmakologi atau biologi senyawa ligan ditentukan berdasarkan kriteria Lipinski's Rule of Five. Analisis toksisitas dengan menggunakan Toxtree dan admetSAR. Berdasarkan pada hasil penelitian diperoleh 5 kandidat senyawa potensial sebagai tuberkulosis, yaitu DC-159a, Delamid, BTZ043, TBA-7371, dan PBTZ169 dengan nilai binding affinity berturut-turut -9,7; -9,6; -9,5; -9,4; dan -9,1 $\mathrm{kkal} / \mathrm{mol}$.Hasil analisis Lipinski menunjukkan bahwa semua senyawa tersebut memenuhi kriteria Lipinski. Sedangkan hasil uji toksisitas menunjukkan bahwa semua senyawa tersebut tidak berpotensi bersifat karsinogenik dan mutagenik
\end{abstract}

Kata kunci : Inhibitor, Protein Tirosin Kinase, Senyawa turunan sintetik, Tuberkulosis.

\begin{abstract}
Mycobacterium tuberculosis (Mtb) is a bacteria that causes infection in Tuberculosis (TB). Most of the TB drugs developed at this time were started 40 years ago. The drug allows resistance to Mycobacterium tuberculosis. Therefore, it is necessary to develop new drugs that can treat TB. Protein tyrosine kinase can be targeted for TB treatment because it plays a key role in Mtb physiology and pathogenesis. In this study, an analysis of the effectiveness of synthetic derivative compounds as inhibitors of molecular docking against protein tyrosine kinase, which plays an important role in tuberculosis, was conducted. Synthetic derivatives were subjected to molecular docking analyzes. Determination of inhibition constant values and visualization of drug interactions were carried out using Pymol and Discovery Visualizer. The pharmacological or biological activity of the ligand compounds is determined based on Lipinski's Rule of Five criteria. Toxicity analysis using Toxtree and admetSAR. Based on the research results obtained 5 potential compound candidates as tuberculosis, namely DC-159a, Delamid, BTZ-043, TBA-7371, and PBTZ169 with binding affinity value respectively $-9.7 ;-9.6 ;-9.5 ;-9.4$; and $-9.1 \mathrm{kcal} /$ mol. The results of Lipinski analysis showed that all of these compounds met Lipinski's criteria. Meanwhile, the results of the toxicity test showed that all these compounds had no potential to be carcinogenic and mutagenic
\end{abstract}

.Keywords: Inhibitors, Synthetic hereditary compounds, Tuberculosis, Tyrosine Kinase Protein. 


\section{PENDAHULUAN}

Penyakit TB disebabkan oleh bakteri Mtb yang dapat menginfeksi saluran pernapasan pada manusia. Berdasarkan pada data WHO tahun 2017, terdapat penderita TB sebanyak 10,4 juta orang dengan jumlah pasein meninggal sebesar 1,7 juta kasus.Sebanyak 0,4 juta pasein meninggal tersebut dinyatakan positif HIV. Berdasarkan laporan WHO tersebut, 1 juta anak terkena TB dan 250.000 anak meninggal akibat TB [1].

Jumlah penderita yang meninggal dari penyakit TB ini dapat disebababkan karena disebabkan tingkat kepatuhan pasein dalam pengobatan serta resistensi bakteri terhadap obat yang sudah ada. Oleh karena itu perlu dikembangkan obat yang dapat mengatasi masalah resistensi tersebut. Obat baru tersebut diharapkan dapat diminum secara oral, serta dosisi yang efektif dalam mematikan bakteri Mtb, dan murah. Pengembangan target baru pada pengobatan TB dengan mempertimbangkan waktu durasi terapi yang singkat, efektifitas terhadap bakteri resisten serta kompatibilitas pemberian bersama antiretroviral [2]. Senyawa-senyawa baru yang dikembangkan memiliki aktivitas potensial untuk melawan strain Mtb resisten. Perkembangan obat baru tersebut menjadi harapan bagi kemajuan pengobatan TB [3].

Penelitian lima tahun terakhir ini, senyawa dari bahan sintetik turunan seperti Lipiarmycin, Rotenone, Thiolactomycin, Aminopyridines, Indoles, Macrolides, Pyrazinamide, Analogues, Antimicrobial Peptides, Imidazoles, Riminophenazines.Menjadi senyawa yang dapat berkembang sebagai penemuan obat anti tuberkulosis baru. Senyawa anti-TB baru harus mengatasi masalah dengan baik saat ini [4].

Protein tirosin kinase memainkan peran kunci dalam fisiologi Mycobacterium tuberculosis (Mtb) dan patogenesis. Penelitian sebelumnya telah menunjukkan bahwa protein tirosin kinase A yang disekresikan, PtpA, adalah penting untuk penghambatan Mtb [5].

Berdasarkan pada latar belakang Penelitian sebelumnya telah menunjukkan bahwa protein tirosin kinase A yang disekresikan, PtpA, adalah penting untuk penghambatan Mtb [5]. Oleh karena itu dilakukan penelitian terhadap efektifitas dari senyawa-senyawa turunan sintetik yang berperan penting sebagai inhibitor pada penambatan molekular terhadap protein tirosin kinase A pada penyakit tuberkulosis. Penelitian ini bertujuan untuk mendapatkan data interaksi secara molekular dari turunan senyawa obat sintetik yang dapat dijadikan kandidat obat tuberkulois baru yang dapat mengatasi masalah resistensi obat.

\section{METODE PENELITIAN}

Bahan: Struktur 3 dimensi makromolekul Protein tirosin kinase diunduh dari Protein Data Bank (PDB) melalui situs (https://www.rcsb.org/). Struktur ligan dari struktur senyawa bahan sintetik turunan dari Lipiarmycin, Rotenone, Thiolactomycin, Aminopyridines, Indoles, Macrolides, Pyrazinamide, Analogues, Antimicrobial Peptides, Imidazoles, Riminophenazines. Ligan tersebut dan ligan pembanding gefinitif diunduh melalui Pubchem melalui situs (https://pubchem.ncbi.nlm.nih.gov/). Alat: Perangkat keras yang digunakan adalah laptop Lenovo dengan spesifikasi Intel core I5 2,50 ghz, RAM 4,0 gb, sistem operasi yang digunakan Windows 8, Autodock Tools ( Phyton 2.7.13 dan MGL Tools 1.5.6) (Scripps Research Institute), Open Babel 2.4.1, Discovery Visualizer 2016, Autodock Vina, Pymol, Marvin Sketch, Avogadro, Toxtree, Lipinski's Rule of Five (http://www.scfbio-

iitd.res.in/software/drugdesign/lipinski.jsp), situs online admetSAR@LMMD (http://lmmd.ecust.edu.cn/admetsar1/predict/).

\section{Metode}

Penyiapan Struktur Makromolekul dan Ligan

Makromolekul Protein tirosin kinase diunduh dalam format *.pdb. Makromolekul protein dipreparasi dengan menggunakan program Discovery Studio Visualizer 2016. Hasil preparasi disimpan dalam format*.pdb. Optimasi residu dilakukan dengan Autodock Tools. Hasilnya disimpan dalam format $*$.pdbqt.

Struktur ligan yang digunakan untuk pengujian berupa struktur 3 dimensi yang diunduh dari situs PubChem dengan format *.sdf. Kemudian format ligan diubah dalam bentuk *.pdb menggunakan program Open Babel. Ligan tersebut dioptimasi dengan Autodock Tools. Hasil optimasi disimpan dalam format *.pdbqt.

\section{Simulasi Penambatan Molekuler \\ Penambatan molekuler dilakukan menggunakan software Autodock vina. Protein dan ligan yang telah disimpan dalam format*}


.pdbqt disalin ke dalam folder vina. Simulasi vina dilakukan melalui command prompt dengan perintah docking "vina --config conf.txt --log log.txt" untuk mengetahui nilai affinity (kkal/mol) dan Root Mean Square Distance (RMSD), nilai ini menunjukkan kestabilan ikatan ligan dengan protein target, semakin kecil nilainya maka ikatan antar ligan dengan protein target semakin stabil dan efek yang ditimbulkan ligan terhadap protein target semakin besar [6]. Hasil penambatan dilakukan berdasarkan pada nilai energi bebas Gibbs terbaik. Hasil penambatan molekul dengan energi Gibbs terbaik kemudian divisualisasikan melalui program dan Pymol.

\section{Analisis Lipinski's Rule of Five}

Analisis Lipinski's dilakukan menggunakan situs online Lipinski's Rule of Five (http://www.scfbioiitd.res.in/software/drugdesign/lipinski.jsp).

Berkas file ligan dimasukan ke dalam kolom input dengan format *.pdb. Parameter analisis ini terdiri atas berat molekul ( $<500$ dalton), jumlah hidrogen donor $(<5)$, jumlah akseptor hidrogen $(<10)$, nilai $\log \mathrm{P}(<5)$, dan refraktivitas molar sebaiknya diantara 40 - 130 [7]. Dari hasil analisis Lipinski's Rule of Five dipilih 10\% senyawa potensial dari kriteria tersebut. Kemudian kandidat senyawa potensial berdasarkan analisis Lipinski's Rule of Five selanjutnya diuji toksisitasnya menggunakan program Toxtree dan situs online admetSAR@LMMD.

\section{AnalisisToksisitas}

Analisis toksisitas dilakukan dengan menggunakan program Toxtree dan situs online admetSAR. Parameter yang dilihat pada uji toksisitas menggunakan Toxtree adalah Kroes TTC decision tree, Cramer Rules dan Benigni and Bossa rulebase. Prediksi dilakukan dengan memasukan berkas ligan dengan format *.sdf. Sedangkan parameter yang dilihat pada uji toksisitas melalui situs online admetSAR (http://lmmd.ecust.edu.cn/admetsar1/predict/) adalah parameter Rat Acute Toxicity $\left(\mathrm{LD}_{50}\right)$.
Prediksi ini dilakukan dengan memasukan berkas ligan dengan format *SMILES.

\section{HASIL DAN PEMBAHASAN Struktur Makromolekul dan Ligan}

Identitas protein yang digunakan pada penelitian ini adalah $6 \mathrm{~F} 2 \mathrm{X}$ yang merupakan struktur microbakterium Receptor pada bakteri tuberkolosis yang diperoleh dari difraksi sinar-X dengan resolusi $1,87 \AA$. Struktur makromolekul yang diperoleh tersebut merupakan inhibitor kompleks dan molekul air. Molekul air harus dihilangkan sebelum proses penambatan berlangsung karena dapat mengganggu proses penambatan. Waktu penambatan akan menjadi lebih lama dengan adanya molekul air. Hal ini dapat disebabkan kompleksitas dari variabel persamaan matematika yang perlu diselesaikan [8]. Selain itu, ligan air yang terikat pada sisi aktif dapat menghalangi ligan lain untuk berikatan. Perangkat lunak Discovery Visualizer digunakan untuk memisahkan residu yang tidak diperlukan dari makromolekul.

Optimasi pada makromolekul dilakukan dengan cara penambahan atom hidrogen serta pengaturan parameter grid box. Penyesuaian terhadap $\mathrm{pH}$ sitoplasma sel $(\mathrm{pH} \sim 7)$ dapat dilakukan dengan peanambahan atom hidrogen [9]. Atom hidrogen yang ditambahkan berperan dalam struktur 3 dimensi dalam bentuk interaksi dengan ligan. Atom ini besifat polar sehingga dapat membentuk ikatan hidrogen antara ligan dan makromolekul [10].

Muatan makromolekul dapat diperbaiki dengan pengaturan merge non-polar. Perbaikan dilakukan dengan menambahkan muatan gasteiger. Penyesuaian muatan ini bertujuan untuk mendapatkan hasil perhitungan dengan benar interaksi antara ligan dan makromolekul. Pengaturan grid box dilakukan untuk menentukan daerah simulasi tempat ligan yang akan di tambat pada protein target. Kemudian file struktur makromolekul disimpan dalam format *.pdbqt. Struktur makromolekul dapat dilihat pada Gambar 1. 


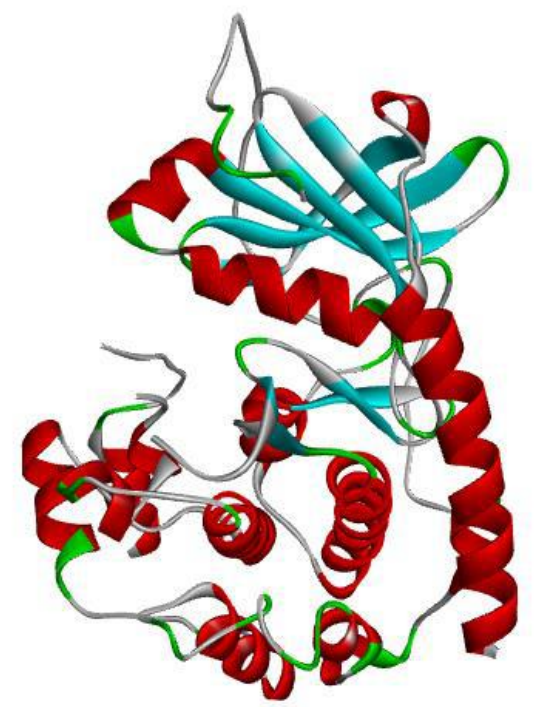

Gambar 1. Struktur makromolekul Protein Tirosin Kinase A (PDB ID: 6F2X)

Pada penelitian ini ligan yang ditambatkan meliputi ligan pembanding (gefinitif), senyawa induk (protein tirosin kinase ) dan ligan uji (ligan yang berpotensi menghambat bakteri tuberkolosis yang sudah bermutan. Pada penelitian ini ligan uji merupakan senyawa baru sedang berada pada pengembangan Mekanismenya adalah melalui pemutusan protein tirosin fosfatase untuk penghambatan bakteri tuberkolosis [5].

Pada tahap ini baik ligan uji maupun ligan pembanding dilakukan pengoptimasian terlebih dahulu dengan menambahkan muatan gasteiger. Penambahan muatan dilakukan dengan Autodock Tools. Muatan gesteiger ini secara otomatis akan ditambahkan pada ligan ketika dibuka dengan Autodock Tools. Semua file ligan disimpan dalam format *.pdbqt. Penentuan kandidat senyawa potensial didasarkan pada parameter pengujian penambatan molekuler, analisis Lipinski's Rule of Five serta uji toksisitas. Pada pengujian penambatan molekuler, senyawa dilihat berdasarkan nilai binding affinity dari senyawa tersebut. Afinitas antara reseptor dengan ligan semakin tinggi dapat dilihat dari nilai binding affinity dari suatu senyawa senakin rendah, sebaliknya jika nilai binding affinity dari suatu senyawa semakin besar maka afinitas antara reseptor dan ligan semakin rendah [11]. Pada penelitian ini senyawa yang diuji sebanyak 22 ligan yang berpotensi menghambat bacteri tuberkolosis yang sudah bermutan (Tabel 1).

\section{Kandidat Senyawa Potensial}

Dari hasil penambatan molekuler, diperoleh 7 kandidat senyawa terbaik berdasarkan nilai binding affinity terkecil. Dari 7 kandidat senyawa terbaik didapatkan ligan yang paling berpotensi menghambat bacteri tuberkolosis dengan kode ligan TBI-166 yang memiliki nilai binding affinity sebesar $-12,5 \mathrm{kkal} / \mathrm{mol}$. Nilai ini lebih besar jika dibandingkan dengan senyawa pembandingnya (gefinitib) yaitu sebesar $-9,1 \mathrm{kkal} / \mathrm{mol}$. Namun jika senyawa tersebut tidak memenuhi kriteria dari analisis Lipinski's Rule of Five. Senyawa ini belum bias dikatakan baik.

\section{Tabel 1. Senyawa ligan kandidat obat}

\begin{tabular}{cccc}
\hline No. & Kandidat senyawa uji & & Kandidat senyawa uji \\
\hline 1 & TBI-166 & 12 & Q203 \\
2 & CP-ZEN-45 & 13 & PBTZ169 \\
3 & SQ609 & 14 & Sutezolid \\
4 & SQ641 & 15 & Linezolid
\end{tabular}




\begin{tabular}{cccc}
5 & 1599 & 16 & Rifapentine \\
6 & DC-159a & 17 & Bedaquiline \\
7 & Q201 & 18 & Pretomanid \\
8 & BTZ-043 & 19 & Pyrazinamide \\
9 & TBA-7371 & 20 & Levofloxacin \\
10 & TBA-354 & 21 & Moxifloxacin \\
11 & GSK-070 & 22 & Delamanid \\
\hline
\end{tabular}

Kemudian dari 22 senyawa yang akan di uji di pilih 16 kandidat senyawa terbaik berdasarkan pengujian penambatan molekuler, selanjutnya senyawa tersebut dianalisis aktivitas biologisnya menggunakan analisis Lipinski's Rule of Five. Dari analisis ini didapatkan bahwa semua senyawa tersebut memenuhi persyaratan dari analisis tersebut. Jadi dapat dinyatakan bahwa semua senyawa memiliki aktivitas biologis yang baik sebagai obat. Namun pada tahap ini senyawa yang dipilih sebagai kandidat senyawa terbaik juga berdasarkan pengujian penambatan molekul Jika senyawa tersebut dinyatakan memenuhi persyaratan Lipinski's Rule of Five namun nilai binding affinity terlalu besar, maka senyawa tersebut tidak dapat dikategorikan sebagai kandidat senyawa terbaik. Kemudian dari analisis ini diperoleh 16 kandidat senyawa terbaik yang selanjutnya akan diuji toksisitasnya.

Pada uji toksisitas, 16 kandidat senyawa terbaik diuji menggunakan perangkat lunak Toxtree dan admetSAR. Pada uji toksisitas diperoleh 5 kandidat senyawa potensial sebagai antituberkolosis yang sudah bermutan dengan parameter karsinogenitas, mutagenitas dan nilai $\mathrm{LD}_{50}$ yang memenuhi persyaratan. Selanjutnya 5 kandidat senyawa potensial ini dianalisis dan divisualisasi interaksinya untuk melihat interaksi antara ligan dengan reseptor, jarak atom antara ligan dengan ikatan serta gugus fungsi yang berikatan dengan reseptor. Data hasil pengujian kandidat senyawa potensial dapat dilihat pada Gambar 2.

\section{Analisis Lipinski's Rule of Five}

Pada penelitian ini diharapkan senyawa sintetis yang diduga dapat menghambat bakteri tuberkulosis yang sudah bermutan tidak hanya mampu berikatan dengan reseptor target secara baik, namun juga diharapkan senyawa tersebut mempunyai aktivitas biologis yang baik sebagai obat. Oleh karena itu, senyawa kandidat terbaik berdasarkan nilai binding affinity perlu dianalisis terlebih dahulu menggunakan analisis Lipinski's Rule of Five (R05). R05 merupakan aturan yang dapat digunakan dalam obat untuk mengevaluasi aktivitas farmakologi maupun biologi obat tersebut sehingga dapat dibuat menjadi obat oral pada manusia.

Berdasarkan aturan tersebut, maka 22 senyawa tersebut dianalisis untuk mengetahui senyawa yang diuji memenuhi syarat atau tidaknya sesuai aturan Lipinski's Rule of Five menggunakan server online Lipinski's Rule of Five. Dari hasil penapisan Lipinski's Rule of Five menunjukan bahwa dari 22 senyawa sintesis yang berpotensi menghambat bakteri tuberkulosis didapatkan 16 senyawa memenuhi kriteria tersebut, sehingga kemungkinan aktif secara klinik bila diberikan secara oral karena aktivitas biologisnya baik. Sehingga pada analisis ini 16 kandidat senyawa terbaik berdasarkan analisis Lipinski's Rule of Five dan nilai binding affinity terkecil. Kemudian 16 kandidat senyawa terbaik ini selanjutnya diuji toksisitasnya. 


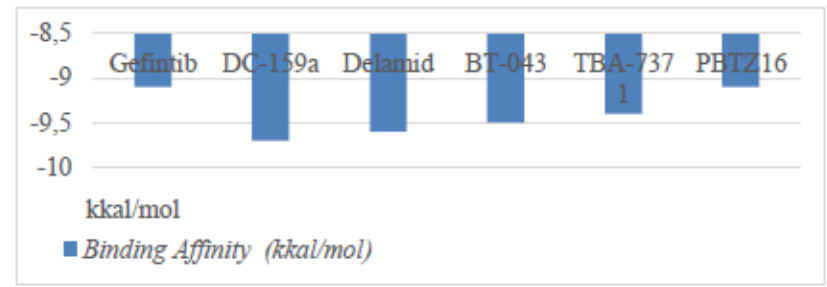

(a)

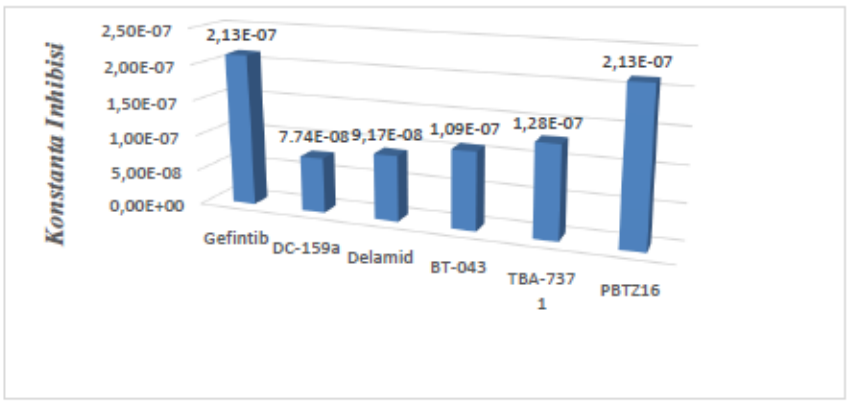

(b)

Gambar 2. Hasil pengujian kandidat senyawa potensial (a) binding affinity, dan (b) konstanta inhibisi.

\section{Toksisitas}

Dalam perancangan senyawa baru yang akan digunakan sebagai obat selain senyawa tersebut mampu berikatan dengan reseptor target dan memiliki aktivitas biologis yang baik, senyawa tersebut juga tentunya harus aman bagi tubuh serta tidak menimbulkan efek toksis bagi tubuh jika senyawa obat tersebut dimetabolisme di dalam tubuh. Oleh karena itu, dalam perancangan senyawa obat baru perlu dilakukan prediksi toksisitas terhadap senyawa tersebut. Pada penelitian ini, uji toksisitas dilakukan untuk memprediksi tingkat toksisitas senyawa ligan uji yang meliputi, prediksi mutagenitas, karsinogenitas, batas paparan senyawa obat pada manusia serta nilai $\mathrm{LD}_{50}$.

Hasil penapisan toksisitas dengan parameter Benigni and Bossa rulebase 16 senyawa menunjukan hasil yang negatif terhadap genotoksik maupun non-genotoksik karsinogenik. Sedangkan resiko mutagenitas tidak ditunjukan oleh parameter ini. Sedangkan pada senyawa dengan kode ligan uji BTZ-043, GSK-070, Levofloxacin, linezolid, PBTZ169, Pyrazinaide dan Sutezolid menunjukan hasil bahwa senyawa tersebut tidak bersifat genotoksik karsinogenik dan tidak bersifat non-genoksiksik karsinogeik. Selain itu pada parameter ini senyawa dengan kode ligan 1599, DC-159a, Delamid, Maxifloxacin, Pretomanid, SQ609, TBA-354, dan TBA-771 menunjukan hasil bahwa senyawa tersebut tersebut positif terhadap genotoksik dan tidak bersifat non-genotoksik karsinogenik. Kemudian pada senyawa dengan kode ligan uji Q201 menunjukan hasil bahwa senyawa tersebut positif terhadap genotoksik dan tidak bersifat nongenotoksik karsinogenik.serta tidak berpotensi bersifat karsinogenik berdasakan QSAR.

\section{Tabel 2. Hasil Prediksi Toksisitas menggunakan Toxtree}

\begin{tabular}{llll}
\hline Kode Ligan & $\begin{array}{l}\text { Cramer } \\
\text { Rules }\end{array}$ & $\begin{array}{l}\text { Benigni and Bossa } \\
\text { rulebase }\end{array}$ & $\begin{array}{l}\text { Kroes TTC decision } \\
\text { tree }\end{array}$ \\
\hline Gefinitib & III & 8.9 & I \\
1599 & III & 1.9 & II
\end{tabular}




$\begin{array}{llll}\text { BTZ-043 } & \text { III } & 8.9 & \text { I } \\ \text { DC-159a } & \text { III } & 1.9 & \text { II } \\ \text { Delamanid } & \text { III } & 1.9 & \text { II } \\ \text { GSK-070 } & \text { III } & 8.9 & \text { I } \\ \text { Levofloxacin } & \text { III } & 8.9 & \text { I } \\ \text { Linezolid } & \text { III } & 8.9 & \text { I } \\ \text { Maxifloxacin } & \text { III } & 1.9 & \text { II } \\ \text { PBTZ169 } & \text { III } & 8.9 & \text { I } \\ \text { Pretomanid } & \text { III } & 1.9 & \text { II } \\ \text { Pyrazinamide } & \text { III } & 8.9 & \text { I } \\ \text { Q201 } & \text { III } & 1.6 .9 & \text { II } \\ \text { SQ609 } & \text { III } & 1.9 & \text { II } \\ \text { Sutezolid } & \text { III } & 8.9 & \text { I } \\ \text { TBA-354 } & \text { III } & 1.9 & \text { II } \\ \text { TBA-7371 } & \text { III } & 1.9 & \text { II }\end{array}$

Keterangan :

I: Senyawa diduga tidak aman dan memiliki resiko bagi kesehatan

II: Resiko toksisitas dapat diabaikan

III: High (Class III)

1: Peringatan struktur untuk sifat genotoksik karsinogenik

3: Berpotensi mengalami mutasi oleh S. Typhimurium berdasarkan QSAR

4: Tidak berpotensi mengalami mutasi oleh $S$. Typhimurium berdasarkan $Q S A R$

6: Tidak berpotensi bersifat karsinogen berdasarkan QSAR

8: Tidak bersifat genotoksik karsinogenik

9: Tidak bersifat non-genotoksik karsinogenik

Pada ligan pembanding menunjukan hasil bahwa senyawa tersebut negatif terhadap genotoksik dan nongenotoksik karsinogenik. Hasil parameter Kroes TTC decision tree menunjukkan bahwa dari 16 senyawa modifikasi termasuk ke dalam kategori 1 yaitu tidak aman dan memiliki resiko bagi kesehatan. Sedangkan senyawa dengan kode ligan 1599, DC-159a, Delamid, Maxifloxacin, Pretomanid, Q201, SQ609, TBA354 dan TBA-771 termasuk ke dalam kategori 2 yaitu menunjukan bahwa resiko toksisitas dari senyawa dapat diabaikan. Hasil ligan pembanding (Gefinitib) menujukan hasil bahwa senyawa tersebut termasuk ke dalam kategori 1 yaitu senyawa tidak aman dan memiliki resiko bagi kesehatan. Hasil prediksi toksisitas ligan uji menggunakan Toxtree dapat dilihat pada Tabel 2 . Selanjutnya ligan uji diprediksi toksisitasnya menggunakan admetSAR untuk mengetahui nilai $\mathrm{LD}_{50}$ dari senyawa tersebut. Pada tahap ini ligan uji dianalisis dengan memasukan file ligan dengan format *SMILES. Parameter yang digunakan pada analisis ini adalah nilai Rat Acute Toxicity $\left(\mathrm{LD}_{50}\right)$. Dari hasil prediksi menggunakan admetSAR didapatkan hasil bahwa semua ligan masuk ke dalam kategori tidak toksik karena rentang nilai dosisnya $>15 \mathrm{~g} / \mathrm{kg}$. Hasil prediksi toksisitas menggunakan admetSAR dapat dilihat pada Gambar 3. Penapisan dari sebanyak 16 kandidat senyawa terbaik didapatkan 5 kandidat senyawa potensial sebagai antituberkulosis. Kandidat senyawa potensial didapatkan dengan menganalisis ikatan hidrogen dan ikatan hidrofob yang terbentuk dari senyawa modifikasi dengan protein target. Lima kandidat senyawa potensial yang diperoleh yaitu DC- 159a, Delamid, BTZ043, TBA-7371, dan PBTZ169 (Tabel 3). 
67 Harry Noviardi et, al.,( Penapisan Molekular Kandidat Obat Sintetik ...)

\section{lethal Doses}

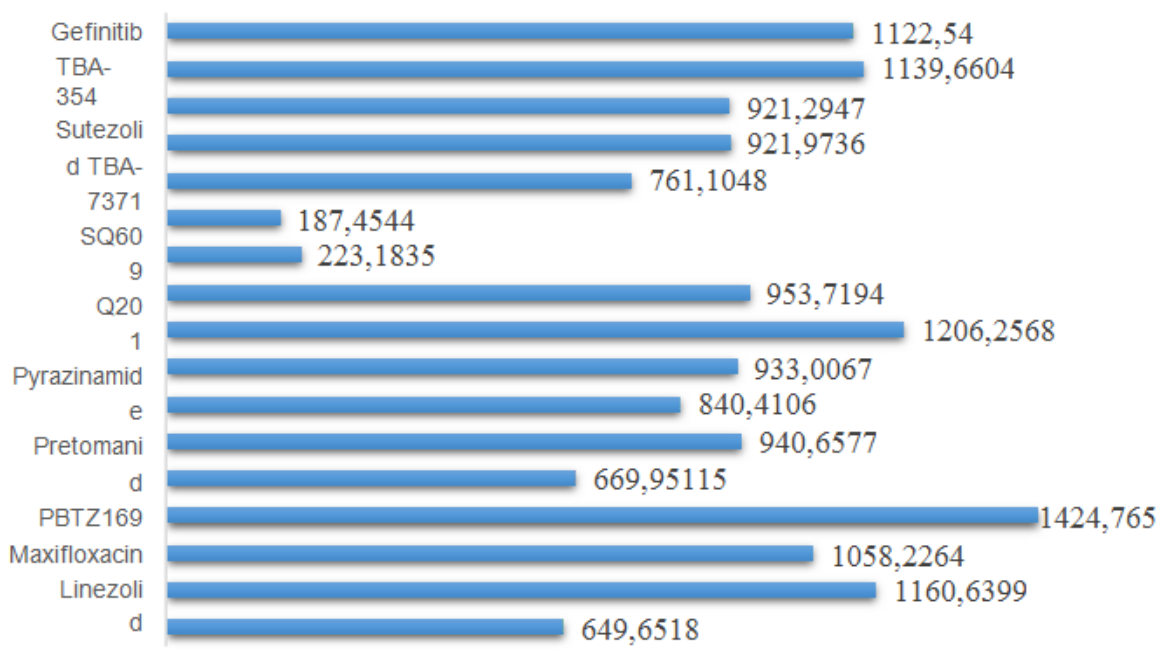

Gambar 3. Hasil Prediksi Toksisitas menggunakan admetSAR

\section{Tabel 3. Kandidat Senyawa Potensial}

Kod

\section{Rumus Molekul Ligan}

Ligan

Gefinitib

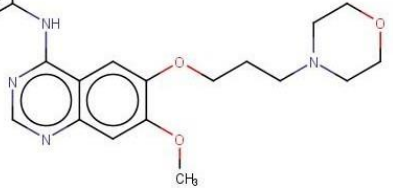

DC-159a

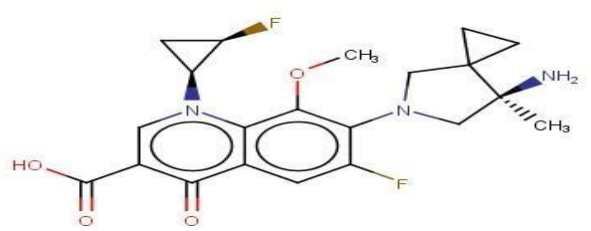

Delamid

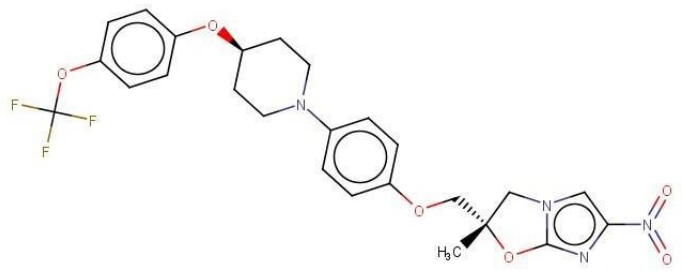

Binding Affinity

(kkal/mol)

$-9,1$

$-9,7$

$-9,6$ 
BTZ-043

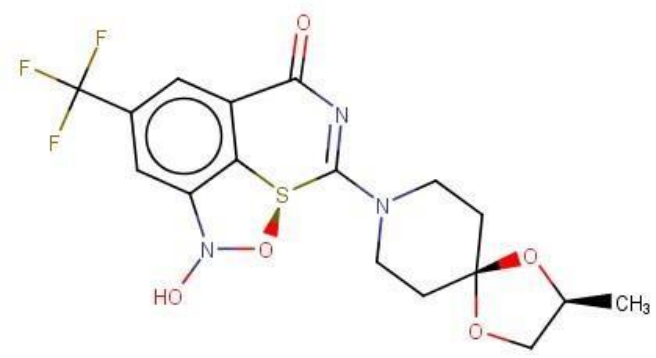

TBA-7371

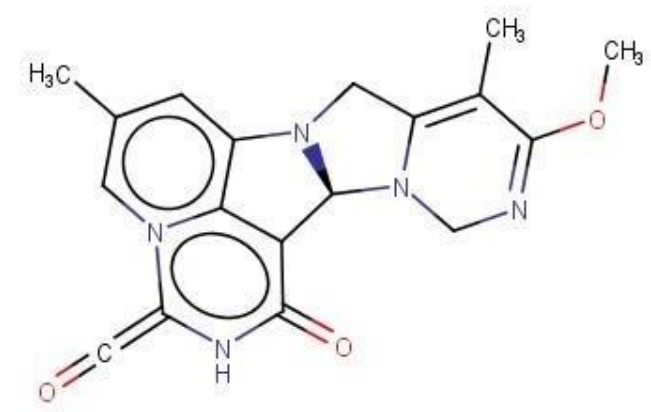

PBTZ16

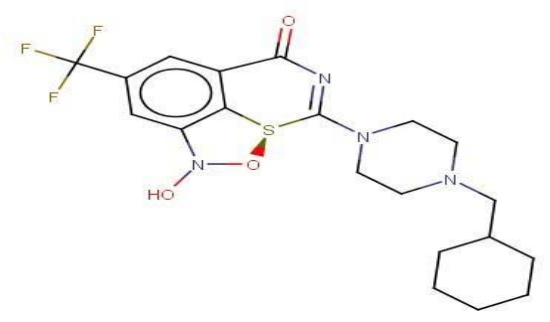

\section{SIMPULAN}

Berdasarkan pada hasil penelitian didapatkan 5 kandidat senyawa potensial sebagai antituberkulosis dengan parameter nilai binding affinity, konstanta inhibisi, aturan Lipinski's Rule of Five yang meliputi berat molekul, $\mathrm{H}$ - donor, $\mathrm{H}$ akseptor, nilai $\log \mathrm{P}$ serta refraktivitas molar dan parameter uji toksisitas yang meliputi uji Benigni and Bossa rulebase, Cramer Rules, Kroes TTC decision tree dan nilai LD50. Kandidat senyawa potensial didapatkan dengan menganalisis ikatan

\section{DAFTAR PUSTAKA}

[1] [WHO] World Health Organization. Global Tuberculosis Report 2017. 2017. WHO. Geneva. 15-49.

[2] Tripathi, R.P., Tewari, N., Dwivedi, N., Tiwari, V. K., 2005, Fighting Tuberculosis: an Old.Disease with New Challenges, Medical Research Reviews, 25, 93-131. hidrogen dan ikatan hidrofob yang terbentuk dari senyawa modifikasi dengan protein target. Lima kandidat senyawa potensial yang diperoleh yaitu DC- 159a, Delamid, BTZ-043, TBA-7371, dan PBTZ169 dengan nilai binding affinity berturuturut $-9,7 \mathrm{kkal} / \mathrm{mol},-9,6 \mathrm{kkal} / \mathrm{mol},-9,5 \mathrm{kkal} / \mathrm{mol}$, $9,4 \mathrm{kkal} / \mathrm{mol}$ dan $-9,1 \mathrm{kkal} / \mathrm{mol}$. Kemudian dari hasil pengujian toksisitas senyawa potensial yang telah di uji menunjukan hasil yang baik atau tidak berpotensi toksisitas.

[3] Villemagne B, Crauste C, Flipo M, Baulard AR, Déprez B, 2012, Tuberculosis: the drug development pipeline at a glance. European Journal of Medicinal Chemistry. 51: 1-16

[4] Quan, D., Nagalingam, G., Payne, R., Triccas, J. A. 2017. New tuberculosis drug leads from naturally occurring compounds. International journal of infectious diseases : IJID : official publication of the International Society 
69 Harry Noviardi et, al.,( Penapisan Molekular Kandidat Obat Sintetik ...)

for Infectious Diseases, 56, 212-220.

[8] Cole, J. C., J. W. Nissink \& O. Taylor. 2005. Protein-Ligand Docking and

[5] Wong, D., Li, W., Chao, J. D., Zhou, P., Narula, G., Tsui, C., Ko, M., Xie, J., Martinez-Frailes, C., Av-Gay, Y. 2018. Protein tyrosine kinase, PtkA, is required for Mycobacterium tuberculosis growth in macrophages. Scientific reports. 8(1), 155.

[6] Mubarok, M.F., Dewi, A., Ainun, W., Jenie., Septiseptyani, E.P., Edy, M. 2008. Peningkatan Aktivitas Sitotoksik Doxorubisin Terhadap Sel Kanker Payudara MCF-7 Menggunakan Ekstrak Etanolik Daun Awar-Awar (Ficus septia Burm.F). Yogyakarta: Fakultas Farmasi Universitas Gadjah Mada. Prosiding Kongres Ilmiah ISFI. XVI: 1-8.

[7] Lipinski, C.A. 2004. Lead- and drug-like compounds: the rule-of-five revolution. Drug Discov. Today Technol. 1, 337-341. Alvarez \& B. Shoichet. Virtual Screening in Drug Discovery. Boca Raton: CRC Press

[9] Drie, J. H. 2005. Pharmacophore-Based Virtual Screening: A Partical Prespective. In J. Alvarez \& B. Shoichet. Virtual Screening in Drug Discovery. Boca Raton: CRC Press.

[10] Yannuar, Arry. 2012.Penambatan Molekular Praktek dan Aplikasi pada Virtual Screening. Depok: Fakultas Farmasi Universitas Indonesia.

[11] Saputri, K.E., Nurul, F., Erwinda, K., Dedy P., Broto, S. 2016. Docking Moleculer potensi antidiabetes Melitus Tipe 2 Turunan Zerumbon sebagai Inhibitor Aldosa Reduktase dengan Autodock Vina. Chimica et Natura 4(1): 16-20. 